\title{
Thermal Comfort Zone for Thai People
}

\author{
Juntakan Taweekun ${ }^{*}$, Ar-U-Wat Tantiwichien \\ Department of Mechanical Engineering Faculty of Engineering, Prince of Songkla University, Hat Yai, Songkhla, Thailand

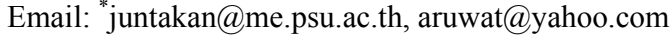

Received February 12, 2013; revised March 23, 2013; accepted March 30, 2013

Copyright (C) 2013 Juntakan Taweekun, Ar-U-Wat Tantiwichien. This is an open access article distributed under the Creative Commons Attribution License, which permits unrestricted use, distribution, and reproduction in any medium, provided the original work is properly cited.

\begin{abstract}
Radiant cooling system for thermal comfort of Thai people was developed. Questionnaires for subjective experiments were examined for development of radiant cooling system for thermal comfort. Thermal sensation, humid sensation and air movement sensation were used for thermal comfort assessment. The Predicted Mean Vote (PMV) value was used for thermal comfort evaluation and it was observed that the $P M V$ values are in the comfortable ranges during 18:00 to 10:00 for air velocity $0.2 \mathrm{~m} / \mathrm{s}$ and $0.4 \mathrm{~m} / \mathrm{s}$. Comfortable periods are extended for higher air velocity. Neutral temperatures are in the ranges of $26.44^{\circ} \mathrm{C}-33.60^{\circ} \mathrm{C}$. The percentage number of dissatisfied $(P P D)$ value for each air velocity was also investigate and the value of $P P D$ is five for zero value of $P M V$. Simulation and experimental results were evaluated by using three indicators, namely, the coefficient of variation $(C V)$, the mean bias error $(M B E)$ and Chi-Square $\left(\chi^{2}\right)$. The values of $C V, M B E$ and $\chi^{2}$ for mean radiant temperature are $14.52 \%, 1.54 \%$ and $3.95^{\circ} \mathrm{C}$, respectively. Zones of acceptable thermal environment were developed for Thai People. Results revealed that the comfortable zones of Thai people are in the ranges of relative humidity $50 \%-70 \%$ and effective temperatures $(E T) 24^{\circ} \mathrm{C}$ $27^{\circ} \mathrm{C}$.
\end{abstract}

Keywords: Thermal Comfort Zone; Radiant Cooling System; Neutral Temperature

\section{Introduction}

Electricity consumption in Thailand is approximately $44 \%, 24 \%$ and $23 \%$ of the total electricity use for industrial, commercial and residential sectors, respectively [1]. For residential buildings in urban and suburban areas, air-conditioning is also widely used approximately $70 \%$ of the total energy use. Webb (1952) pioneered thermal studies in Singapore for humid tropical regions [2]. Busch (1990) studied on field experiment in naturally ventilated office buildings in Bangkok, Thailand indicated a neutrality of $28.5^{\circ} \mathrm{C} \mathrm{ET}$, while $24.5^{\circ} \mathrm{C} \mathrm{ET}$ was observed in air-conditioned buildings [3]. Neutral temperature for office workers was $26.7^{\circ} \mathrm{C}$ in Jakarta, Indonesia [4]. The use of radiant cooling system was suggested to offer quiet comfort and energy efficiency superior to conventional air-conditioning system [5]. Zones of acceptable operative temperature and humidity for people with light activity were developed by ASHRAE. The lower limit of $E T$ for winter and the upper limit of $E T$ for summer are $20^{\circ} \mathrm{C}$ and $26^{\circ} \mathrm{C}$ [6]. In the previous studies,

${ }^{*}$ Corresponding author. effects of humidity and air velocity on thermal comfort were seldom discussed. This study concentrates on the use of radiant cooling system considering effects of temperature, humidity, air velocity, metabolic rate, clothing level by subjective experiments. Subjective experiments will be carried out to evaluate thermal comfort under the radiant cooling system of Thai people. The values of $P M V$ and $P P D$ are considered for thermal comfort evaluation. Measured data and data obtained from questionnaire are used for development of radiant cooling system for thermal comfort. The values of $C V, M B E$ and $\chi^{2}$ are used to investigate experimental and simulation results.

\section{Methodology}

\subsection{Design of Radiant Cooling System}

In this stage, the radiant cooling panel, control system and relevant equipment were designed. The designed areas of the radiant cooling panels are $32 \mathrm{~m}^{2}$ which calculated from heat gain into the experimental room divided by the panel cooling capacity. 


\subsection{Experimental Set Up and Data Collection}

The experiment was set up at the low energy house in Prince of Songkla University, Thailand. The radiant cooling panels were constructed from copper tube bonded to aluminium sheet. The cooling tower produces cool water with temperature $25^{\circ} \mathrm{C}$ and supplies to the wall and ceiling radiant cooling panels with closed system. Temperature sensors installed at surfaces of cooling panels are controlled by PID controller for opening solenoid valve at $0 \%-100 \%$. Flow diagram of radiant cooling system is illustrated in Figure 1.

Thermal comfort field investigation was referred to Class I as specified in ASHRAE and IS0 standards. Three heights of measurement above floor level are 0.1 , 0.6 and $1.2 \mathrm{~m}$. Experimental conditions for humidity and air movement were controlled by a humidifier and air speed level. Temperature and humidity sensors were used to measure the temperature and relative humidity of interior and exterior air. Surface temperatures of opaque wall and radiant cooling panels were measured by thermocouple type $\mathrm{K}$. Mean radiant temperature was also recorded by globe thermometer. All of these data were continuous recorded to data logger. The interior air speed, electrical consumption and metabolic rate were measured by anemometer, continuous power meter and heart rate meter, respectively.

\subsection{Questionnaire Procedure}

Research objectives, outcomes of the research and how to answer the questionnaire are clarified to the subjects. The first part asks about personal information age, gender, weight, height, education level, type of clothes that the subjects wore on the day of investigation. In the second part, questions were asked about thermal sensation, humid sensation and air movement sensation in response to the room conditions. The subjects are required to make only one choice from the scales as shown in Table 1 for each question. The subjects voted at relative humidity from $50 \%$ to $90 \%$ and air velocity passing through the body in the ranges of $0.2-1.0 \mathrm{~m} / \mathrm{s}$.

\subsection{Development of Radiant Cooling System for Thermal Comfort of Thai People}

The measured data and data obtained from questionnaire are used for development of radiant cooling system for thermal comfort of Thai people. Values of $P M V$ and $P P D$ are investigated for thermal comfort evaluation as given in Equations (1) and (2). Value of $P M V$ is used to describe the vote and imbalance condition. Ranges of $P M V$ for thermal comfort conditions are -0.5 to 0.5 (Comfortable); 0.5 to 1.0 (Warm); -1.0 to -0.5 (Cool); over 1.0 (Unacceptably Warm) and under -1.0 (Unacceptably cool) [7].

$$
\begin{aligned}
& P M V=[0.303 \exp (-0.036 M)+0.028] L . \\
& P P D=100-95 \exp \left[-\left(0.03353 P M V^{4}+0.2179 P M V^{2}\right)\right] .
\end{aligned}
$$

where $L$ is imbalance between $(M-W R)$ and rate of heat dissipation $\left(\mathrm{W} / \mathrm{m}^{2}\right), M$ is metabolic rate $\left(\mathrm{W} / \mathrm{m}^{2}\right)$ and $\mathrm{WR}$ is work rate $\left(\mathrm{W} / \mathrm{m}^{2}\right)$ which obtained from equation $5.5-15(M-0.8)$.

\section{Results and Discussions}

\subsection{Predicted Mean Vote and Percentage Number of Dissatisfied Evaluation}

Thermal comfort can be obtained in the wider ranges at the higher air velocity. It was observed that the $P M V$ values are in the range of $-1-1$ which are in the comfortable ranges during 18:00 to $10: 00$ at air velocity 0.2 $\mathrm{m} / \mathrm{s}$ and $0.4 \mathrm{~m} / \mathrm{s}$ as illustrated in Figure 2. Comfortable

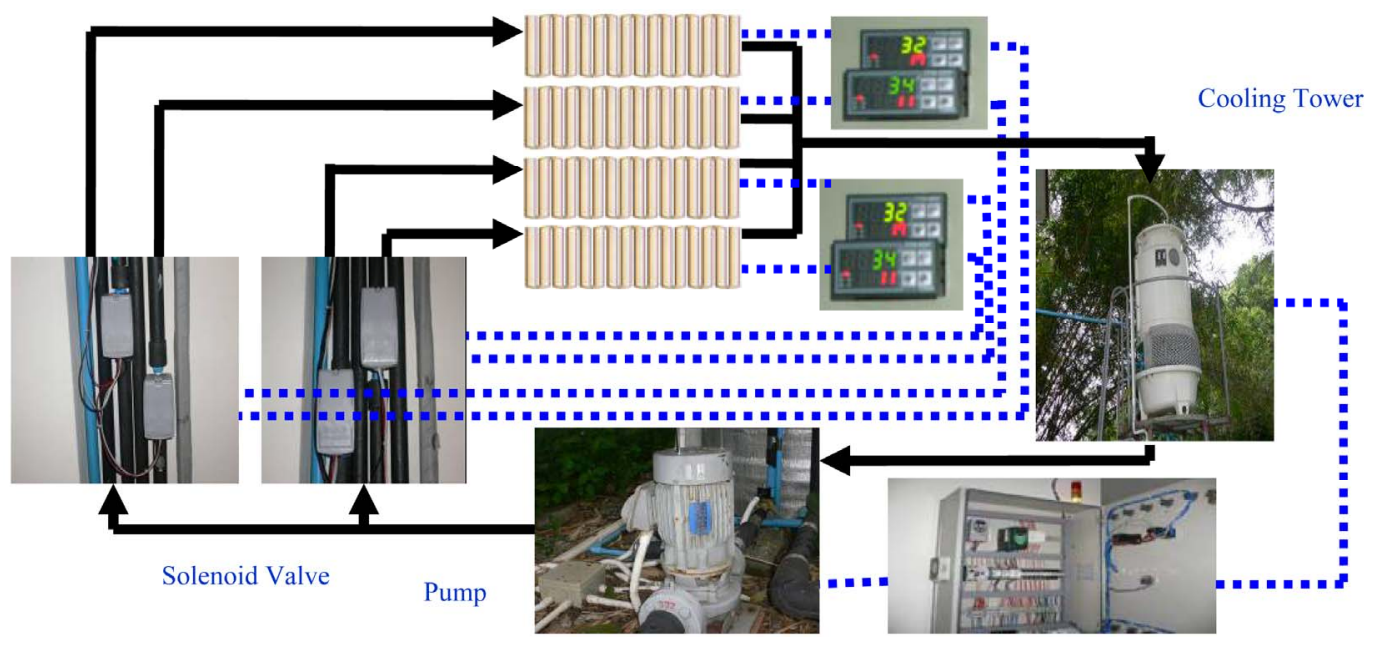

Figure 1. Flow diagram of radiant cooling system. 
periods are extended in the ranges of 15:00 to 12:00 at higher air velocity. The relationships between $P M V$ and $P P D$ values for each air velocity are also examined. The value of $P P D$ is five for zero value of $P M V$. The number reaches " 10 " when $P M V$ deviates from zero by 0.5 and 25 when $P M V$ deviates by 1.0 .

\subsection{Thermal Comfort Assessment}

All subjects are in seat and quiet (met 1.0) with short shirt and long sleeve. The subjects voted in the range of relative humidity $50 \%-90 \%$ with air velocity $0.2-1.0$ $\mathrm{m} / \mathrm{s}$.

\subsubsection{Humid Sensation Analysis}

Results implied that the subjects feel mostly just right and slightly humid at air velocity $0.2,0.4$ and $0.6 \mathrm{~m} / \mathrm{s}$. Moreover, the subjects prefer mainly just right and also feel slightly dry at air velocity 0.8 and $1.0 \mathrm{~m} / \mathrm{s}$. The humid sensations are mostly voted just right in the ranges of relative humidity $50 \%$ to $60 \%$ which is in the ranges refer to ASHRAE Standard. The humid acceptability for Thai subjects decreases at the higher relative humidity and are below $80 \%$ for all cases of relative humidity above $70 \%$ as illustrated in Figure 3.

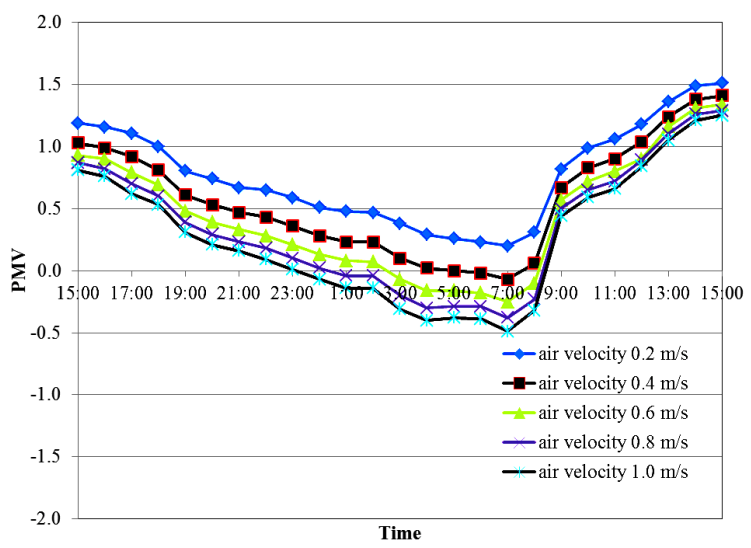

Figure 2. Comparisons of PMV values.

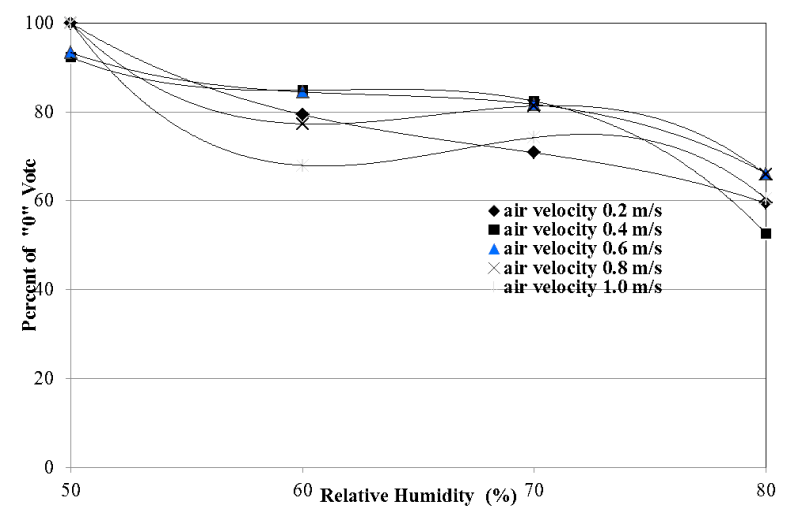

Figure 3. Humid acceptability for air velocity $0.2-1.0 \mathrm{~m} / \mathrm{s}$.
Table 1. Thermal, humid and air movement sensation scales.

\begin{tabular}{cccc}
\hline Value & Thermal Sensation & Humid Sensation & $\begin{array}{c}\text { Air Movement } \\
\text { Sensation }\end{array}$ \\
\hline+3 & hot & humid & too breezy \\
+2 & warm & slightly humid & breezy \\
+1 & slightly warm & just right & just right \\
0 & neutral & slightly dry & too still \\
-1 & slightly cool & dry & \\
-2 & cool & & \\
-3 & cold & & \\
\hline
\end{tabular}

Table 2. Thermal sensation voted (TSV) equations and neutral temperature.

\begin{tabular}{cccc}
\hline $\begin{array}{c}\text { Air Velocity } \\
(\mathrm{m} / \mathrm{s})\end{array}$ & TSV Equation & $R^{2}$ & $\begin{array}{c}\text { Neutral } \\
\text { Temperature }\left({ }^{\circ} \mathrm{C}\right)\end{array}$ \\
\hline 0.2 & $T S V=0.193 T_{i}-5.102$ & 0.8966 & $26.44+0.9$ \\
0.4 & $T S V=0.17 T_{i}-4.573$ & 0.9219 & $26.90+0.9$ \\
0.6 & $T S V=0.206 T_{i}-5.919$ & 0.7969 & $28.73+0.9$ \\
0.8 & $T S V=0.275 T_{i}-8.165$ & 0.9128 & $29.69+0.9$ \\
1.0 & $T S V=0.192 T_{i}-6.259$ & 0.8122 & $32.60+0.9$ \\
\hline
\end{tabular}

\subsubsection{Air Movement Sensation Analysis}

The subjects feel mostly just right at air velocity $0.2 \mathrm{~m} / \mathrm{s}$ and $0.4 \mathrm{~m} / \mathrm{s}$. The votes for breezy and too breezy are obtained at the higher air velocity $0.8 \mathrm{~m} / \mathrm{s}$ and $1 \mathrm{~m} / \mathrm{s}$. The highest air movement acceptability can be obtained in the ranges of $25^{\circ} \mathrm{C}$ and $29^{\circ} \mathrm{C}$ for air velocity $0.2 \mathrm{~m} / \mathrm{s}$ and in the ranges of $26^{\circ} \mathrm{C}$ and $30^{\circ} \mathrm{C}$ for air velocity $0.4 \mathrm{~m} / \mathrm{s}$.

\subsubsection{Thermal Sensation Analysis}

The relationships between thermal sensation vote and interior air temperature $\left(T_{i}\right)$ in the ranges of relative humidity $50 \%$ to $90 \%$ at air velocity 0.4 and $0.6 \mathrm{~m} / \mathrm{s}$ are given in Figures 4 and 5, respectively. The corresponding neutral temperature is the temperature at which the regression line crosses $\mathrm{x}$-axis.

Results showed that neutral temperatures are in the ranges of $26.44^{\circ} \mathrm{C}-32.60^{\circ} \mathrm{C}$ as given in Table 2 .

Subjective experimental results for air velocity $0.4 \mathrm{~m} / \mathrm{s}$ and various relative humidity are shown in Table 3.

The relations between the percentage of the subjects voting " 0 " and the interior temperature are shown in Figure 6 for air velocity $0.4 \mathrm{~m} / \mathrm{s}$ and Figure 7 for air velocity $0.6 \mathrm{~m} / \mathrm{s}$. Temperature and air velocity have significant effect to thermal sensation vote. The higher percent of vote " 0 " were obtained in case of air velocity 0.2 $\mathrm{m} / \mathrm{s}$ and $0.4 \mathrm{~m} / \mathrm{s}$. The comfort temperature can be extended to $32.60^{\circ} \mathrm{C}$ in case of air velocity $1.0 \mathrm{~m} / \mathrm{s}$. Never- 
Table 3. Distribution of thermal sensation votes at air velocity $0.4 \mathrm{~m} / \mathrm{s}$.

\begin{tabular}{|c|c|c|c|c|c|c|c|c|c|c|c|}
\hline \multirow{2}{*}{$\begin{array}{c}\text { Temperature } \\
\left({ }^{\circ} \mathrm{C}\right)\end{array}$} & \multirow{2}{*}{$\begin{array}{l}\mathrm{RH} \\
(\%)\end{array}$} & \multicolumn{7}{|c|}{ Number of Thermal Sensation Vote } & \multirow{2}{*}{$\begin{array}{c}\text { Frequency } \\
\text { Number }\end{array}$} & \multirow{2}{*}{$\begin{array}{c}\text { Percent of " } 0 \text { " } \\
\text { Vote }\end{array}$} & \multirow{2}{*}{ Mean Vote } \\
\hline & & -3 & -2 & -1 & 0 & 1 & 2 & 3 & & & \\
\hline $24+0.9$ & $80-90$ & & 4 & 8 & 20 & & & & 32 & 62.50 & -0.50 \\
\hline \multirow[t]{2}{*}{$25+0.9$} & $50-60$ & & & 6 & 22 & & & & 28 & 78.57 & -0.21 \\
\hline & $70-80$ & & & 6 & 22 & & & & 28 & 78.57 & -0.21 \\
\hline \multirow[t]{4}{*}{$26+0.9$} & $50-60$ & & 2 & 2 & 26 & & & & 30 & 86.67 & -0.20 \\
\hline & $60-70$ & & & 6 & 22 & & & & 28 & 78.57 & -0.21 \\
\hline & $70-80$ & & & & 22 & & & & 22 & 100 & 0.00 \\
\hline & $80-90$ & & & & 45 & & & & 45 & 100 & 0.00 \\
\hline \multirow[t]{4}{*}{$27+0.9$} & $50-60$ & & & & 33 & 6 & & & 39 & 84.62 & 0.15 \\
\hline & $60-70$ & & & 13 & 25 & & & & 38 & 65.79 & -0.34 \\
\hline & $70-80$ & & & 13 & 78 & 6 & & & 97 & 80.41 & 0.07 \\
\hline & $80-90$ & & & 6 & 32 & 6 & 6 & & 50 & 64.00 & 0.24 \\
\hline $28+0.9$ & $60-70$ & & & & 58 & & & & 58 & 100 & 0.00 \\
\hline \multirow[t]{2}{*}{$29+0.9$} & $60-70$ & & & & 39 & 6 & & & 45 & 86.67 & 0.13 \\
\hline & $70-80$ & & & & 25 & 2 & 1 & & 28 & 89.29 & 0.14 \\
\hline \multirow[t]{2}{*}{$30+0.9$} & $60-70$ & & & & 5 & 8 & 13 & & 26 & 19.23 & 1.31 \\
\hline & $70-80$ & & & & 32 & 6 & & & 38 & 84.21 & 0.16 \\
\hline $31+0.9$ & $60-70$ & & & & 9 & 15 & 3 & & 27 & 33.33 & 0.78 \\
\hline $32+0.9$ & $70-80$ & & & & 8 & 15 & 4 & & 27 & 29.63 & 0.85 \\
\hline
\end{tabular}

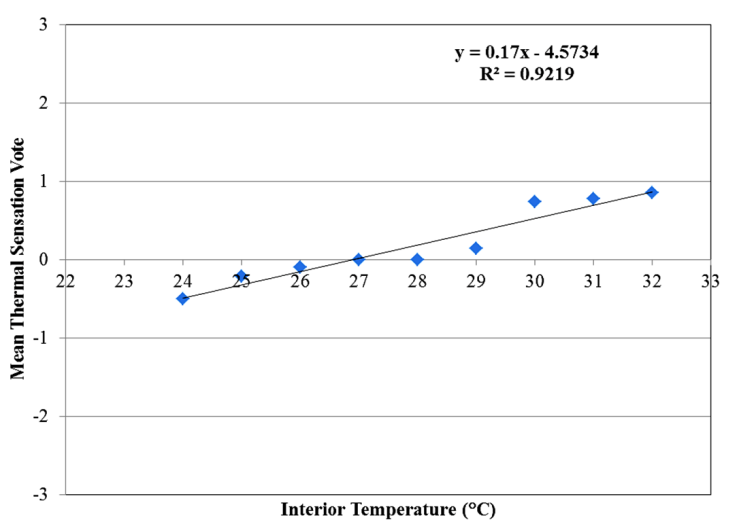

Figure 4. Relationships between mean thermal sensation vote and interior temperature at air velocity $0.4 \mathrm{~m} / \mathrm{s}$.

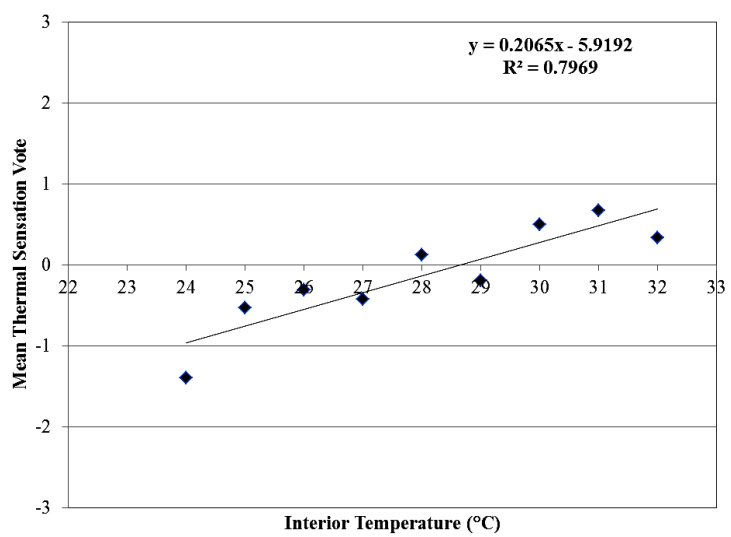

Figure 5. Relationships between mean thermal sensation vote and interior temperature at air velocity $0.6 \mathrm{~m} / \mathrm{s}$.

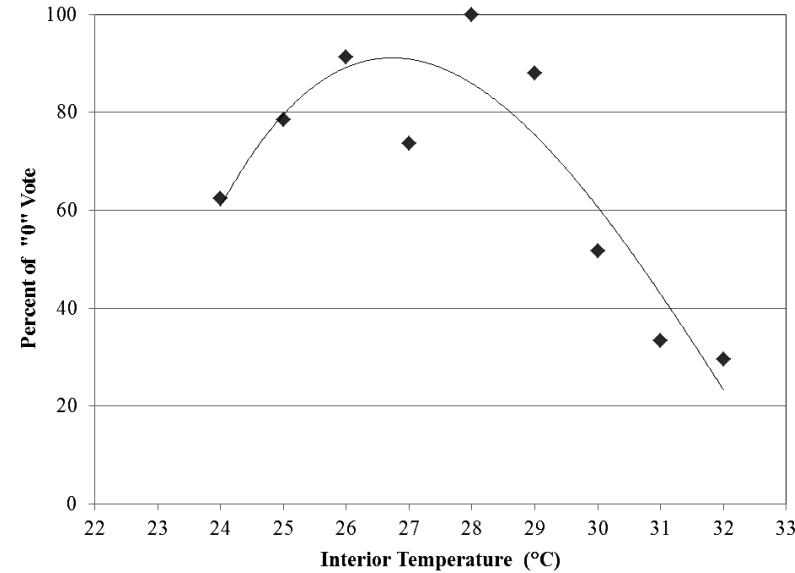

Figure 6. Thermal acceptability for air velocity $0.4 \mathrm{~m} / \mathrm{s}$.

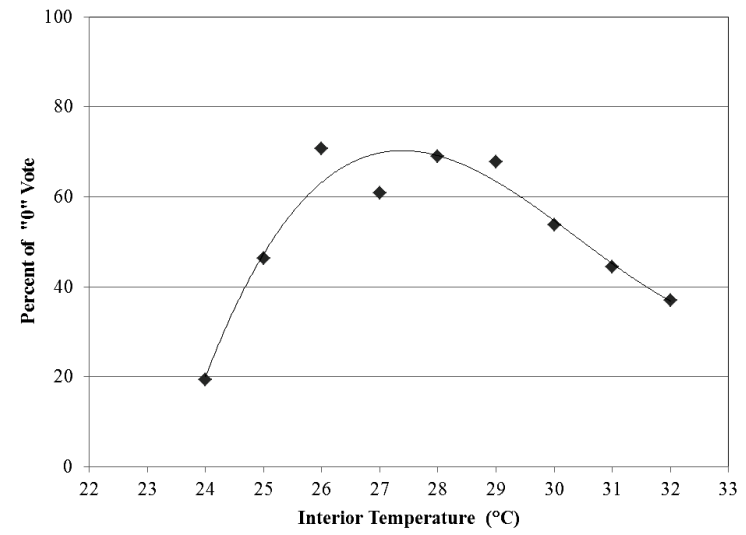

Figure 7. Thermal acceptability for air velocity $0.6 \mathrm{~m} / \mathrm{s}$. 
theless, thermal acceptability for Thai subjects at air velocity $1.0 \mathrm{~m} / \mathrm{s}$ for percent of vote " 0 " are only $37 \%$ which supports recommendation by ASHRAE as air velocity limited to $0.8 \mathrm{~m} / \mathrm{s}$ to avoid a sensation of draft, which occurs when there is non-uniform heat transfer between different parts of the body.

\subsection{Statistic Evaluation}

This study uses three indicators to evaluate the experimental and simulation results, namely $C V, M B E$ and $\chi^{2}$. EnergyPlus Program was used in this study. These indicators have been extensively used for estimation of the accuracy of neural networks and other black-box type models predicting electrical consumption [8-10]. The coefficient of variation is the root mean square error divided by the mean value of the actual output. The resultant values of $C V, M B E$ and $\chi^{2}$ for mean radiant temperature are $14.52 \%, 1.54 \%$ and $3.95^{\circ} \mathrm{C}$, respectively.

\subsection{Thermal Comfort Zone}

As mentioned earlier, the lower limit and upper limit of effective temperature is $24^{\circ} \mathrm{C}$, and $26^{\circ} \mathrm{C}$, respectively and the upper limit of relative humidity is $60 \%$ developed by ASHRAE. In this study, experimental results with the values of clothing level, type of activity and air speed are used to develop zone of acceptable thermal environment of Thai People. Experimental results revealed that the comfortable zones of Thai people are in the ranges of relative humidity $50 \%-70 \%$ and effective temperatures $24^{\circ} \mathrm{C}-27^{\circ} \mathrm{C}$ for air velocity $0.2 \mathrm{~m} / \mathrm{s}$.

\section{Conclusion}

Experimental results implied that radiant cooling system can be applied for buildings under tropical climate and cooling tower can provide cool water for radiant cooling panels. At the higher air velocity, thermal comfort range can be obtained at the higher temperature. Thermal comfort zone for Thai people has wider ranges than ASHRAE comfort zone. This is due to high relative humidity throughout the year in Thailand and the people can adapt in the wider ranges.

\section{Acknowledgements}

This research was financially supported by the Energy
Policy and Planning Office (EPPO), Ministry of Energy, Thailand and Prince of Songkla University for providing the research scholarships.

\section{REFERENCES}

[1] http://www.eppo.go.th

[2] C. G. Webb, "On Some Observation of Indoor Climate in Malaya," Journal of the Institution of Heating and Ventilating Engineers, Vol. 20, No. 204, 1959, pp. 189-195.

[3] J. F. Busch, "Thermal Responses to the Thai Office Environment," ASHRAE Transactions, Vol. 96, No. 1, 1990, pp. 859-872.

[4] T. H. Karyono, "Higher PMV Causes Higher Energy Consumption in Air-Conditioned Buildings: A Case Study in Jakarta, Indonesia," In: Standards for Thermal Comfort: Indoor Air Temperature Standards for the 21st Century, Chapman \& Hall, New York, 1995, pp. 219-226.

[5] T. Imarori, T. Omori and K. Bogaki, "Thermal Comfort and Energy Consumption of the Radiant Ceiling Panel System: Comparison with All-Air System," Energy and Buildings, Vol. 30, No. 2, 1999, pp. 167-175. doi:10.1016/S0378-7788(98)00084-X

[6] American Society of Heating, Refrigerating and Air Conditioning Engineers (ASHRAE), "Thermal Environmental Conditions for Human Occupancy," ANSI/ASHRAE Standard 55-1992, ASHRAE, Atlanta, 1992.

[7] P. O. Fanger, "Thermal Comfort Analysis and Applications in Environmental Engineering," Mcgraw-Hill, New York, 1970.

[8] W. J. Stevenson, "Using Artificial Neural Nets to Predict Building Energy Parameters," ASHRAE Transactions, Vol. 100, No. 2, 1994, pp. 1081-1087.

[9] J. F. Kreider, D. Claridge, P. S. Curtiss, R. Dodier, J. Haberl and M. Krarti, "Recurrent Neural Networks for Building Energy Use Prediction and System Identification: A Progress Report," ASME Journal of Solar Energy Engineering, Vol. 117, No. 3, 1995, pp. 161-166. doi:10.1115/1.2847757

[10] A. Dhar, T. A. Reddy and D. E. Claridge, "Modeling Hourly Energy Use in Commercial Buildings with Fourier Series Functional Forms," ASME Journal of Solar Energy Engineering, Vol. 120, No. 3, 1998, pp. 217-223. doi:10.1115/1.2888072 